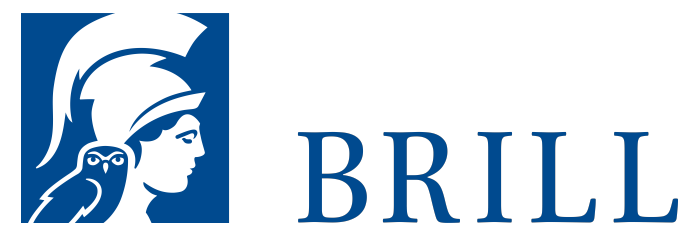

\title{
Generaloberst Ludwig Beck
}

Eine Biographie. Herausgegeben mit Unterstützung des Militärgeschichtlichen Forschungsamtes, Potsdam

Authors: Ruth Müller-Blessing and Klaus-Jürgen Müller

Klaus-Jürgen Müller, einer der namhaftesten Militär- und Zeithistoriker Deutschlands, legt seine seit langem erwartete große Biographie über Ludwig Beck vor. Sie ist die Summe seiner langjährigen Auseinandersetzung mit dem Leben dieses Offiziers, der von 1935 bis 1938 als Generalstabschef des Heeres Mitgestalter der neuen Wehrmacht war, aber während der Sudetenkrise 1938 als einziger unter den militärischen Entscheidungsträgern aus Protest gegen Hitlers Kriegspolitik zurücktrat. Am 2o. Juli 1944 opferte Beck als einer der führenden Köpfe des nationalkonservativen Widerstands sein Leben. Müller stellt das Leben Becks nicht, wie andere es häufig taten, unter einen einzigen zentralen Aspekt, den des Widerstands. Das griffe für einen Mann, der 40 Jahre seines Lebens unter drei verschiedenen politischen Ordnungen im aktiven Dienst verbrachte, viel zu kurz. Müller ordnet Beck vielmehr in die Entwicklung des deutschen Offizierkorps vom Zenit des Kaiserreichs bis zum Ende des Zweiten Weltkriegs ein. Ein großes Buch, das viele neue Erkenntnisse eröffnet: über Beck als Person, über die Gruppe, der er angehörte: die preußischdeutsche Militärelite, und über die Entwicklung und Struktur des militärischen Widerstands gegen Hitler.

Müller begreift Beck als Ausnahmeerscheinung innerhalb seiner Offiziersgeneration - als Typus des kultivierten, gebildeten Bürgers, dessen von der Familie...

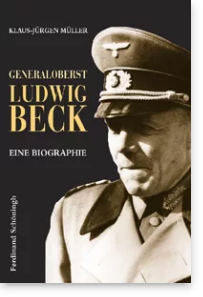

Pages: 834 Seiten, $40 \mathrm{~s} / \mathrm{w}$ Abb.

Language:

German

Subjects:

Modern History, History

Publisher: Brill | Schöningh

E-Book (PDF)

Released online: 15 Jul 2019

ISBN: $978-3^{-}$

657-72874-9

List price

USD $\$ 63.00$

Hardback

Publication date: 24 Oct 2007

ISBN: 978-3506-72874-6 
For more information see brill.com

Order information: Order online at brill.com +44330 333 0049 | customerservices@brill.com Submission information: brill.com/authors

Titles published by Brill | Fink, Brill | mentis or Brill | Schöningh: +49(o)715413279216| brill@brocom.de 